\title{
Pricing of fair value instruments reported under International Financial Reporting Standards 7: South African setting
}

\begin{tabular}{|c|c|}
\hline \multicolumn{2}{|c|}{$\begin{array}{l}\text { Authors: } \\
\text { Hopewell Hlatshwayo }{ }^{1} \\
\text { Mbalenhle Zulu }\end{array}$} \\
\hline \multicolumn{2}{|c|}{$\begin{array}{l}\text { Affiliations: } \\
{ }^{1} \text { College of Economic and } \\
\text { Management Sciences, } \\
\text { Department of Accounting, } \\
\text { University of Pretoria, South } \\
\text { Africa }\end{array}$} \\
\hline \multicolumn{2}{|c|}{$\begin{array}{l}{ }^{2} \text { College of Accounting } \\
\text { Sciences, Department of } \\
\text { Financial Accounting, } \\
\text { University of South Africa, } \\
\text { South Africa }\end{array}$} \\
\hline \multicolumn{2}{|c|}{$\begin{array}{l}\text { Corresponding author: } \\
\text { Mbalenhle Zulu, } \\
\text { ezulumm@unisa.ac.za }\end{array}$} \\
\hline \multicolumn{2}{|c|}{$\begin{array}{l}\text { Dates: } \\
\text { Received: } 21 \text { Feb. } 2018 \\
\text { Accepted: } 07 \text { Sept. } 2018 \\
\text { Published: } 15 \text { Jan. } 2019\end{array}$} \\
\hline \multicolumn{2}{|c|}{$\begin{array}{l}\text { How to cite this article: } \\
\text { Hlatshwayo, H. \& Zulu, M., } \\
\text { 2019, 'Pricing of fair value } \\
\text { instruments reported under } \\
\text { International Financial } \\
\text { Reporting Standards 7: South } \\
\text { African setting', South African } \\
\text { Journal of Economic and } \\
\text { Management Sciences 22(1), } \\
\text { a2345. https://doi.org/ } \\
\text { 10.4102/sajems.v22i1.2345 }\end{array}$} \\
\hline \multicolumn{2}{|c|}{$\begin{array}{l}\text { Copyright: } \\
\text { (C) 2019. The Authors. } \\
\text { Licensee: AOSIS. This } \\
\text { is licensed under the } \\
\text { Creative Commons } \\
\text { Attribution License. }\end{array}$} \\
\hline \multicolumn{2}{|l|}{ Read online: } \\
\hline 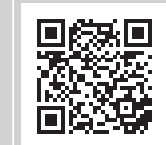 & $\begin{array}{l}\text { Scan this QR } \\
\text { code with your } \\
\text { smart phone or } \\
\text { mobile device } \\
\text { to read online. }\end{array}$ \\
\hline
\end{tabular}

Background: Prior literature established that different fair value levels disclosed in terms of the International Financial Reporting Standards (IFRS) 7 are value relevant.

Setting: This study investigates the market pricing of the different fair value levels, as well as the market reaction towards the fair value hierarchy levels reported in terms of IFRS 7.

Aim: Prior research found inconsistencies in the market pricing of fair value levels. This study seeks to contribute to this debate. It also focuses on the period after comprehensive guidance on how to measure fair value levels was issued.

Methods: Data from 2009 to 2015 were collected from the financial sector companies listed on the Johannesburg Stock Exchange. The study uses the statement of financial position and the Ohlson model to investigate the market pricing of the different fair value levels disclosed in terms of IFRS 7.

Results: The results of the study show that the fair value of assets level 1, 2 and 3, as well as the fair value of liabilities level 3 are value relevant while the fair value of liabilities level 1 and 2 are not value relevant. Furthermore, the market pricing of level 2 and 3 fair value assets and liabilities is not lower for companies with a high debt equity ratio than for companies with a low debt equity ratio. The results further reveal that the pricing of level 3 assets improved with the introduction of IFRS 13 and post the 2008 financial crisis.

Conclusion: Fair value assets across different hierarchy levels are value relevant. On the contrary, fair value liabilities are priced differently across the different hierarchy levels.

\section{Introduction}

The reliability of the fair value measurement of financial instruments has been a long and still ongoing debate in the accounting fraternity (Laux \& Leuz 2009; Procházka 2011). This debate further gained motion during the 2008 economic crisis. Prior literature has defined reliability as faithful representation of financial information in terms of the International Accounting Standards Board's (IASB) Conceptual Framework 2010 (Barth 2007; Kadous, Koonce \& Thayer 2012). The Conceptual Framework further states that information is useful if it is both relevant and faithfully represented (IASB 2010). Deaconu, Buiga and Nistor (2010) argued that there was a lot of criticism levelled against the reliability of fair value accounting (FV-A), but despite this, they suggested that prior research proves that FV-A is value relevant and is usually preferred over historic cost measures by investors. Barth, Beaver and Landsman (2001) define value relevance as the association between accounting information and the market value of equity.

In 2005, the IASB chairman, Sir David Tweedie, introduced the new International Financial Reporting Standards (IFRS) 7 dealing with financial instruments' disclosure. In his introduction, he stated:

The Board believes that the introduction of IFRS 7 will lead to greater transparency about the risks that entities run from the use of financial instruments. This, combined with the new requirements in IAS 1, will provide better information for investors and other users of financial statements to make informed judgements about risk and return (IASB 2005a).

This was particularly important for banks, finance and insurance companies due to their large exposure to financial risk (IASB 2005b). This exposure to financial risk led to an increased demand for additional information on risk exposure and how those risks are managed on financial instruments presented in the statement of financial position. In response to this, the IASB issued IFRS 7 and was 
applicable for all periods starting on or subsequent to 01 January 2007. IFRS 7 specifically addresses the information needs regarding credit risk, market risk and liquidity risk of financial instruments presented in the statement of financial position. Subsequently, the IASB (2008) introduced fair value hierarchy levels accounting in October 2008 through an amendment to IAS 39. Therefore, the disclosure of fair value hierarchy levels as per IFRS 7 became applicable for all periods starting on or subsequent to 01 January 2009.

This study deals with the pricing of fair value instruments (assets and liabilities) disclosed in terms of IFRS 7. Given that the strength of the reliability of the inputs used to calculate the fair values on the different levels is not the same, investors are bound to price these instruments differently (Deaconu et al. 2010). This is also supported by prior literature which found that fair values of non-traded (mark-to-model) financial instruments are significantly less value relevant compared to traded (mark to market) instruments (Petroni \& Wahlen 1995). These fair value hierarchy levels as per IFRS 7 are based on the quality level of inputs used to measure the fair values of financial instruments (Deaconu et al. 2010). IFRS 7.27 specifies 3 fair value levels: level 1 (mark to market), level 2 (mark-to-model) and level 3 (mark-to-model). Level 1 fair value financial instruments have observable market prices and are quoted; hence they are also referred to as mark to market fair values (Goh, $\mathrm{Ng} \& \mathrm{Ow}$ Yong 2009). In contrast to level 1, level 2 financial instruments do not have quoted prices and are not traded in active markets (Deaconu et al. 2010) but calculate the fair values based on observable data from quoted prices of similar items in active markets (Song, Thomas \& Yi 2010). Additionally, level 2 financial instruments are also referred to as mark-to-model instruments. Similar to level 2, level 3 financial instruments do not have quoted prices and are not traded in active markets (Goh et al. 2009). In contrast to level 2 financial instruments, the model used to calculate fair values is based on unobservable or firm generated data and they are also referred to as mark-tomodel instruments (Song et al. 2010).

In this article we specifically explore the effects of the requirements of IFRS 7 on the financial sector in South Africa as other studies (for example, Song et al. 2010 and Goh et al. 2009) in this topic have produced inconsistent results. We examine the market reaction towards the fair value (assets and liabilities) hierarchy levels reported in terms of IFRS 7. A study in this regard is valuable in a South African setting where IFRS is mandatory for all firms listed on the Johannesburg Stock Exchange (JSE). The JSE is relevant as it links the South African economy and the global economy. The JSE is ranked with the largest stock markets in the world, as indicated in the Global Competitiveness Index issued by the World Economic Forum (2016).

Using the balance sheet and Ohlson (1995) model, the results of this study show that fair value of assets level 1, 2 and 3 as well as fair value of liabilities level 3 are value relevant while fair value of liabilities level 1 and 2 are not value relevant. The results also show that the market pricing of level 2 and 3 fair value assets (liabilities) is not lower for companies with a high debt equity ratio than for companies with a low debt equity ratio. Further the results reveal that pricing of level 3 assets improved with the introduction of IFRS 13 and post the 2008 financial crisis. An added advantage of this article is that it examines the differential pricing accross the three fair value levels for IFRS companies when there was a comprehensive and mandatory (IFRS 13) standard on how to measure fair value accross the three hierachy levels and compares it to the pre-IFRS 13 period. Deaconu et al. (2010) allude that before the mandatory application of IFRS 13, to disclose the hierarchy levels in IFRS 7, IFRS companies referred to the Statement of Financial Accounting Standard (SFAS) 157. SFAS 157 is the Financial Accounting Standards Board (FASB) equivalent to IFRS 13; SFAS157 and IFRS 13 deal with measurement of fair value, and thus influence the IFRS 7 disclosures. It is possible that some of the sampled banks in Deaconu et al. did not accurately disclose the hierarchy levels in terms of IFRS 7 during their sample period because there was no comprehensive and mandatory standard prescribing fair value measurement in line with the disclosure requirements of IFRS 7. This article argues that the introduction of IFRS 13 had an impact on investors' perceived risk in respect of liquidity and the information asymmetry of level 2 and 3 fair value assets (liabilities), as there is now a comprehensive standard dealing with fair value measurements. The results of this study will be of interest to standard setters and investors and will assist in understanding the impact of IFRS 7 fair value hierarchy level disclosure in the financial sector in South Africa.

The rest of the article is organised as follows: Section 2 provides the relevant prior literature and states the hypotheses. Section 3 describes the sample selection procedure, data and research method to be used in the study, Section 4 discusses the results of the study, Section 5 deals with the robustness tests and, lastly, Section 6 details the conclusion.

\section{Related literature and hypothesis Fair value}

Fair value measurement is important in this study as the fair values of financial instruments presented in the statement of financial position influence the fair value hierarchy disclosure of IFRS 7. IFRS 13 defines fair value as the price that would be received to sell an asset or paid to transfer a liability in an orderly transaction between market participants at the measurement date (IASB 2011). From the definition above, the challenge is the measurement of assets and liabilities that are not traded in active markets as the fair values have to be estimated using other models.

IFRS 13 is of utmost importance to this study because IFRS 7 became effective before IFRS 13, and the principles on fair value hierarchy levels in IFRS 7 are driven by IFRS 13. Prior to IFRS 13, the IASB did not have an accounting standard that comprehensively dealt with fair values and the arising measurement issues. This article argues that the effective 
application of the fair value hierarchy level disclosure requirements in IFRS 7 is dependent on IFRS 13. This is consistent with Deaconu et al. (2010) who echo the same sentiments and further suggest that early IFRS 7 adopters referred to SFAS 157 for guidance on applying the principles of IFRS 7 before IFRS 13 came into effect. SFAS 157 is the FASB equivalent of the IASB's IFRS 13. SFAS 157 came into effect before IFRS 7 and 13 .

\section{Relevance and reliability of fair values}

Barth et al. (2001) state that value relevance studies often examine the relevance and reliability of the amount in question. It is generally established among scholars in the accounting fraternity that the information content carried by fair valued amounts in the financial statements is relevant (Barth, Beaver \& Landsman 1996; Carrol, Linsmeier \& Petroni 2003; Petroni \& Wahlen 1995). Goh et al. (2009) state that one of FV-A's objectives is to ensure transparency in the valuation of financial items, so as to empower investors to make sound economic decisions.

Similar studies that examine the value relevance of FV-A have produced inconsistent results. A study conducted by Goh et al. (2009), using a sample of American banks, found that level 1 fair value assets are priced significantly differently from level 2 and 3 fair value assets. In addition, they do not record a significant difference between the pricing of level 2 and 3 fair value assets. A study conducted by Song et al. (2010) on a sample of American banks found that level 1 and 2 fair value assets are priced significantly differently from level 3 fair value assets. However, they do not record significant differences in the pricing of level 1 and 2 fair value assets. Another study conducted on a sample of European banks, (Deaconu et al. 2010) found similar results to Song et al. The prior research consulted in this study are value relevance studies and are based on the efficient market theory (Deaconu et al. 2010). These prior studies cover the 2008 financial crisis period and Deaconu et al. (2010) suggest that during that period markets were not efficient. Therefore, the financial crisis might have had confounding effects on the results of these studies and by their own admission, Deaconu et al. cite this as one of the limitations of their study. While these prior studies focused on periods before and during the 2008 financial crisis, this study focuses on the period after the 2008 financial crisis and also compares the period during the financial crisis to the after the financial crisis period.

As management's judgement is required to determine fair values to a certain extent (Dechow, Myers \& Shakespeare 2010), the fair values are inherently subject to measurement error and this creates an incentive for management to manipulate the figures (Song et al. 2010). The combination of information asymmetry and susceptibility of fair values to management manipulation and error cast doubt on the reliability of fair values (Song et al. 2010). Although accounting scholars seem to reach consensus on the relevance of fair values, there is still a debate regarding the reliability of fair values. Some scholars in support of fair value argue that the information content of fair values better captures real volatility and makes financial reporting easy (Song et al. 2010), while other scholars contend that fair values are less verifiable by investors, as they are inherently prone to a greater estimation error and susceptible to manipulation by those charged with governance (Penman 2007). The arguments against FV-A point to an information asymmetry challenge between management and investors or owners. Information asymmetry occurs when people who manage an entity are different from the investors or owners (De Klerk, De Villiers \& Van Staden 2015). Therefore, investors or owners will require relevant information to assess and monitor the performance of management or companies (Healy \& Palepu 2001).

\section{Hypothesis development}

The first hypothesis looks at the value relevance of the three fair value hierarchy levels of IFRS 7. It was established that investors require relevant and reliable information on future earnings and cash flows. We also established that the aim of FV-A is to ensure transparency in the valuation of financial instruments. The requirement of IFRS 7 to disclose inputs and categories of fair valued instruments can be seen as a tool to achieve it.

Disclosure of the different fair value hierarchy levels in terms of IFRS 7 enables investors to assess how fair values were calculated and determine the liquidity of financial instruments and the related information risk (Goh et al. 2009). Therefore, they conclude that level 2 and 3 fair values possess a greater information risk to investors. This is due to the fact that level 1 instruments are traded in active markets and level 2 and 3 are not actively traded but are based on valuation models. It is against this background that Goh et al. (2009) conclude that level 2 and 3 fair values possess a greater information risk to investors as the inputs to the models are not publicly available. Goh et al. further infer that during any economic crisis liquid assets play a crucial role in raising capital and therefore have a price premium as they moderate liquidity surprises (Holmström \& Tirole 2001). In contrast to liquid instruments (level 1), we argue that investors will mark down the fair values of illiquid instruments (level 2 and 3). This argument is supported by Goh et al. who state that during the 2008 financial crisis, a number of banks were adamant that the fair values of their assets were below market value especially level 2 and 3, thus suggesting that investors most likely discounted those assets.

The challenge of information asymmetry (information risk) coupled with fair value measurement error may render the amounts unreliable. Therefore, this article argues that level 2 and 3 fair values are more prone to error because they use models to determine fair value, as was implied in similar studies on this topic (Deaconu et al. 2010; Dechow et al. 2010; Goh et al. 2009). Epstein and Schneider (2008) allude that poor quality information may have a negative impact on prices, thus result in measurement error. We also argue that the information risk regarding level 2 and 3 fair values is high 
compared to level 1, as implied in similar studies on this topic (Deaconu et al. 2010; Dechow et al. 2010; Goh et al. 2009; Song et al. 2010). Investors will discount the prices of assets and liabilities with a high level of information asymmetry (Easley, Hvidkjaer \& O'Hara 2002).

We, therefore, predict that level 1 fair value assets and liabilities will have the strongest association with price per share (value relevance), as these are traded in active markets and subject to less or no estimation errors and information risk. For level 2 fair value assets and liabilities, we predict a lower value relevance compared to level 1, as level 2 assets and liabilities are based on models, but higher than level 3. Lastly, we expect level 3 assets and liabilities to have the lowest value relevance as these are based on unobservable data, hence higher estimation errors and information risk.

Therefore, the first hypothesis is stated as follows:

H1: The strength of the value relevance of financial instruments' fair values is inversely related to the hierarchy level order in IFRS 7.

The second hypothesis deals with the effect of capital adequacy on the pricing of fair value assets and liabilities' hierarchy levels disclosed in terms of IFRS 7. Deaconu et al. (2010) allude that banks with a deficient financial position have an incentive to manage earnings by using their discretion to improve their statement of financial position ratios. Similarly, Goh et al. (2009) found that investors price higher mark-to-model assets for banks with a stronger financial position. Unlike level 1 fair value assets and liabilities, determination of fair values for level 2 and 3 assets and liabilities requires management's discretion. Thus, weaker capital adequacy increases the susceptibility of manipulation of level 2 and 3 fair value assets and liabilities as management's discretion is applied in determining those fair values (Deaconu et al. 2010).

\section{The second hypothesis is stated as follows:}

H2: The market pricing of level 2 and 3 fair value assets and liabilities disclosed in terms of IFRS 7 is predicted to be lower for companies with a high debt equity ratio than for companies with a low debt equity ratio.

The third hypothesis focuses on the effect of the introduction of IFRS 13 on the pricing of financial instruments' different fair value hierarchy levels disclosed in terms of IFRS 7. IFRS 7 became effective before IFRS 13 and prior research suggested that pre-IFRS 13, companies referred to SFAS 157 for guidance to disclose the hierarchy levels in terms of IFRS 7. In this article we argue that there is a possibility that not all IFRS companies referred to SFAS 157 and that has a direct bearing on liquidity and the information risk of fair value hierarchy levels disclosed in terms of IFRS 7 in the pre-IFRS 13 period. As level 1 fair value assets and liabilities are based on observable market prices (Goh et al. 2009), the liquidity and information risk thereof is mitigated. Consequently, we predict that the market will react differently to level 2 and 3 fair value assets and liabilities disclosed during the pre and post-IFRS 13 periods.

The third hypothesis is stated as follows:

H3: The market pricing of level 2 and 3 fair value assets and liabilities disclosed in terms of IFRS 7 is predicted to be different in the pre and post-IFRS 13 period.

The fourth hypothesis deals with the effects of the 2008 financial crisis on the pricing of fair value hierarchy levels of assets and liabilities disclosed in terms of IFRS 7. Similar studies on this topic have produced inconsistent results on the differential pricing across the three fair value hierarchy levels of IFRS 7. We argue that the 2008 financial crisis might have had confounding effects on the pricing of the different hierarchy levels of fair value assets and liabilities disclosed in terms of IFRS 7. Consistent with our argument, Deaconu et al. (2010) allude that during the 2008 financial crisis prices were not efficient and Goh et al. (2009) go a step further and put forward that the 2008 financial crisis might have exacerbated the liquidity and information risk of level 2 and 3 fair value assets. Consequently, these suggestions will impact the differential pricing across the three hierarchy levels during or in the period leading up to the 2008 financial crisis; thus our last hypothesis states:

H4: The differential pricing of fair value assets and liabilities across the three hierarchy levels disclosed in terms of IFRS 7 is predicted to be different during and post the 2008 financial crisis period.

\section{Research method Sample selection}

Our sample consists of companies from the financial sector listed on the JSE which are also listed on the iNet BFA website during the effective sample period. The study specifically targeted the financial sector because a large percentage of the assets in this industry consists of financial instruments. As detailed in Table 1 Panel A, the total sample consisted of 550 observations. The financial sector in South Africa consists of different industries: banking, financial services, insurance, investment instruments and real estate. The robustness tests are stratified to cater for the heterogeneity of the industries as shown in Table 1 Panel B. If the test results were not further stratified it would have distorted the results due to the heterogeneity of the different industries in the financial sector.

\section{Sample period for Hypothesis $\mathbf{1}$ and Hypothesis $\mathbf{2}$}

The effective application of IFRS 7's fair value hierarchy disclosure requirements depends on IFRS 13 which became effective for all periods starting on 01 January 2013. It is therefore expected that companies would have started applying the fair value hierarchy disclosure requirements of IFRS 7 after 2013. The sample therefore covers the 2013-2015 period as per Table 1 Panel C.

\section{Sample period for $\mathrm{H} 3$}

To test whether the application of IFRS 13 had an impact on the market pricing of the fair value levels of assets and 


\begin{tabular}{|c|c|c|c|c|c|c|c|c|c|c|c|c|c|}
\hline \multirow[t]{2}{*}{ Steps } & \multirow[t]{2}{*}{2009} & \multirow[t]{2}{*}{2010} & \multirow[t]{2}{*}{2011} & \multirow[t]{2}{*}{2012} & \multirow[t]{2}{*}{2013} & \multirow[t]{2}{*}{2014} & \multirow[t]{2}{*}{2015} & \multirow[t]{2}{*}{ Total } & \multicolumn{2}{|c|}{ Financial } & \multirow{2}{*}{$\begin{array}{l}\text { Investment } \\
\text { insurance }\end{array}$} & \multirow{2}{*}{$\begin{array}{c}\text { Real } \\
\text { instruments }\end{array}$} & \multirow{2}{*}{$\begin{array}{l}\text { Real } \\
\text { estate }\end{array}$} \\
\hline & & & & & & & & & Banks & Services & & & \\
\hline \multicolumn{14}{|l|}{ Panel A: Sample determination } \\
\hline Total observations & 128 & 128 & 128 & 128 & 128 & 128 & 128 & 896 & - & - & - & - & - \\
\hline Less: companies with no price records in iNet BFA & -63 & -60 & -57 & -50 & -47 & -41 & -28 & -346 & - & - & - & - & - \\
\hline Sample & 65 & 68 & 71 & 78 & 81 & 87 & 100 & 550 & - & - & - & - & - \\
\hline \multicolumn{14}{|c|}{ Panel B: Sample composition per industry in the financial sector } \\
\hline \multicolumn{14}{|c|}{ Panel C: Sample composition to test different hypotheses } \\
\hline Sample for $\mathrm{H} 1$ and $\mathrm{H} 2$ : & - & - & - & - & 81 & 87 & 100 & 268 & - & - & - & - & - \\
\hline Pre-IFRS 13 & 65 & 68 & 71 & 78 & - & - & - & 282 & - & - & - & - & - \\
\hline Post IFRS13 & - & - & - & - & 81 & 87 & 100 & 268 & - & - & - & - & - \\
\hline Sample for H3: & - & - & - & - & - & - & - & 550 & - & - & - & - & - \\
\hline Pre-financial crisis & 65 & 68 & - & - & - & - & - & 133 & - & - & - & - & - \\
\hline Post financial crisis & - & - & 71 & 78 & 81 & 87 & 100 & 417 & - & - & - & - & - \\
\hline
\end{tabular}

Note: The total observations and the process used to arrive at the researched samples to test the four hypotheses are detailed in this table.

$\mathrm{H}$, Hypothesis.

liabilities disclosed in terms of IFRS 7, we compared the reaction of the market to the different fair value levels in the pre- and post-IFRS 13 period to determine if investors were influenced by the pricing guidance in IFRS 13. Our pre-IFRS 13 sampling period is from the date IFRS 7 became effective to the date IFRS 13 became effective: financial years starting on 01 January 2009 to financial years ending on 31 December 2012. The post-IFRS 13 period is all financial years starting on 01 January 2013 to financial years ending on 31 December 2015. The observations for the pre- and post-IFRS 13 period are captured in Table 1 Panel C.

\section{Sample period for $\mathrm{H} 4$}

With H4 we are interested in the impact of the 2008 financial crisis on the market pricing of fair value levels of assets and liabilities disclosed in terms of IFRS 7. To test the hypothesis, we compare the reaction of the market to the different fair value levels in the period during and post the 2008 financial crisis to determine whether investors were influenced by the effects of the 2008 financial crisis to price the fair value hierarchy levels of assets and liabilities differently. The period during the 2008 financial crisis sampling period consists of all financial years starting on 01 January 2009 to financial years ending on 31 December 2010. The post 2008 financial crisis period is all financial years starting on 01 January 2011 to financial years ending on 31 December 2015, as per Table 1 Panel C. We posit that the recession ended in 2009 (Business Cycle Dating Committee 2010), thus allowing a time lag of 1 year for accounting information to be communicated to the public.

\section{Descriptive statistics}

The descriptive statistics of the main variables used in Equation 3 and 4 are depicted in Table 2 Panel A. The number of observations utilised in the regression is 550 companies and the statistics show that a large percentage of the financial sector's fair value assets (FVA) consist of fair value assets hierarchy level 1 (FVA1). The mean of FVA1 is R31.1 billion compared to a mean of R18.62 billion for fair value assets hierarchy level 2 (FVA2) and R6.783 billion for fair value assets hierarchy level3 (FVA3). On the other hand, fair value liabilities
TABLE 2: Descriptive statistics - Panel A: All observations.

\begin{tabular}{lcccccc}
\hline Variables (in billions & Observations & Mean & \multirow{2}{*}{$\begin{array}{l}\text { Standard } \\
\text { deviation }\end{array}$} & \multicolumn{3}{c}{ Percentile } \\
\cline { 5 - 7 } & & & & 25th & 50th & 75th \\
\hline FVA1 & 550 & 31.1 & 142.856 & 0.000 & 0.003 & 1.754 \\
FVA2 & 550 & 18.62 & 59.143 & 0.000 & 0.000 & 0.519 \\
FVA3 & 550 & 6.783 & 21.275 & 0.000 & 0.016 & 2.471 \\
FVL1 & 550 & -11.13 & -81.58 & 0.000 & 0.000 & 0.000 \\
FVL2 & 550 & -22.83 & -75.8354 & 0.000 & 0.000 & -0.431 \\
FVL3 & 550 & -1.006 & -5.393 & 0.000 & 0.000 & 0.000 \\
N-FVA & 550 & 75.41 & 284.129 & 0.434 & 2.059 & 14.053 \\
N-FVL & 550 & -75.9 & -220.627 & -0.191 & -1.622 & -9.068 \\
DE & 550 & 10.07 & 84.209 & 0.33 & 0.914 & 2.963 \\
NI & 550 & 1.778 & 3.866 & 0.012 & 0.206 & 1.586 \\
MVE & 550 & 18.36 & 37.789 & 0.368 & 2.538 & 18.325 \\
\hline
\end{tabular}

Note: This table demonstrates the descriptive statistics of all the variables used in the regression to test the hypotheses. Panel A details the statistics on all the observations used for testing the 4 hypotheses. The sample covers the period from 01 January 2009 to 31 December 2015.

FVA, fair value levels for assets; FVL, fair value levels for liabilities; N-FVA, non-fair value assets; N-FVL, non-fair value liabilities; NI, net income; DE, debt equity ratio; MVE, market value of equity at year end.

(FVL) do not display the same trend as FVA; fair value liabilities hierarchy level 2 (FVL2) are making a large percentage of FVL. The mean of FVL2 is R22.83 billion compared to a mean of R11.13 billion for fair value liabilities hierarchy level 1 (FVL1) and R1.006 billion for fair value liabilities hierarchy level 3 (FVL3). The figures suggest that the FVL of the companies in the financial sector mainly consist of liabilities from financial institutions as opposed to liabilities raised in formal markets. In the financial sector, FVA make up $43 \%$ of the total asset base and FVL make up $32 \%$ of total liabilities. The mean of the debt equity (DE) ratio is 10.07 . The value is tenfold the median value $(0.914)$ which suggests that there are companies with excessive DE ratios that distort the mean. Net income (NI) has a mean of R1.778 billion which is a tenth of the market value of equity (MVE). The means for all variables are greater than the medians, suggesting that there are companies with high variables that are distorting the means. This further necessitates the deflation of the figures.

\section{Empirical model}

The most common models used in value relevance studies are the balance sheet and residual income approach (Deaconu 
et al. 2010). The balance sheet approach assumes that fair value of assets (FVA) less fair value of liabilities (FVL) is equal to market value of equity (MVE) (Landsman 1986). This approach can be stated as follows:

$\mathrm{MVE}=\sum_{i=1}^{m} F V A-\sum_{j=1}^{n} F V L$

[Eqn 1]

Although this approach is easy to understand and apply, the disadvantages of this approach are that it assumes that the fair values of all assets and liabilities can easily be determined which is not the case; secondly, not all assets and liabilities are measured at fair value; thirdly, not all assets and liabilities are recognised in terms of the IFRS 7 (Deaconu et al. 2010). Barth and Landsman (1995) suggest that to capture the effect of off-balance sheet items, net income (NI) should be introduced into the equation to act as a proxy for those items.

The residual income approach or Ohlson (1995) model assumes that the MVE equals the book value of equity ( $B V E$ ) plus residual income (RI) and other information dynamics (U) (Ohlson 1995). The equation can be stated as follows:

$\mathrm{MVE}=\mathrm{BVE}+\alpha 1 \mathrm{RIt}+\alpha 2 \mathrm{Ut}$

[Eqn 2]

$\alpha 1$ and $\alpha 2$ are valuation coefficients reliant on interest rates and information dynamics. Deaconu et al. (2010) state that an advantage of this approach over the balance sheet approach is that it takes time value of money into account and other information that is not captured by accounting numbers. Following Song et al. (2010) and Deaconu et al., we use the modified Ohlson (1995) model to test our hypotheses.

With the modified Ohlson (1995) model we stratified the net assets as follows: non-fair value assets (N-FVA) and liabilities $(N-F V L)$ and the different fair value levels, FVA1, FVA2 and FVA3 for assets and FVL1, FVL2 and FVL3 for liabilities. Following Barth and Clinch (2009), we deflated all our variables with the number of ordinary shares at reporting date to mitigate scaling effects. The equation to test $\mathrm{H} 1$ can be stated as follows:

PPSit $=\beta 0+\beta 1 \mathrm{~N}-\mathrm{FVA}+\beta 2 \mathrm{~N}-\mathrm{FVLit}+$

$\beta 3$ FVA1 it $+\beta 4$ FVA2 2 it $+\beta 5$ FVA3it $+\beta 6$ FVL 1 it +

$\beta 7 \mathrm{FVL} 2$ it $+\beta 8 \mathrm{FVL} 3 \mathrm{it}+\beta 9 \mathrm{NIit}+$ ćit

[Eqn 3]

In Equation 3, PPS represents price per share at financial year-end, NI is net income and $\dot{\varepsilon}$ represents the error of other information (Song et al. 2010).

To test H2, we expand Equation 3 to include the variable HighDebtEquityRatio. This variable acts as proxy for capital adequacy, the variable is 1 for all entities with a debt equity ratio higher than the median debt equity ratio and 0 otherwise. The equation to test $\mathrm{H} 2$ can be stated as follows:

PPSit $=\beta 0+\beta 1 \mathrm{~N}-\mathrm{FVA}+\beta 2 \mathrm{~N}-\mathrm{FVLit}+$

$\beta 3$ FVA 1 it $+\beta 4$ FVA 2 it $+\beta 5$ FVA 3 it +

$\beta 6$ FVL1it $+\beta 7$ FVL2it $+\beta 8$ FVL3it +

$\beta 9 \mathrm{NIit}+\beta 10$ HighDebtEquityit + ćit

[Eqn 4]

To test $\mathrm{H} 3$ we use the difference-in-difference test to determine whether the coefficients of $\beta_{4}\left(\beta_{7}\right)$ and $\beta_{5}\left(\beta_{8}\right)$ in
Equation 3 are different in the pre- and post-IFRS 13 periods. To test $\mathrm{H} 4$ we also use the difference-in-difference test to determine whether the coefficients of $\beta_{3^{\prime}} \beta_{4}$ and $\beta_{5}$ in Equation 3 are different in the period during and post the 2008 financial crisis.

\section{Results}

Table 3 depicts the test results for Equation 3 and tests H1 where the dependent variable is PPS at financial year-end for the respective companies. With $\mathrm{H} 1$ we test whether the strength of FV instruments in relation to PPS is directly related to the strength of the FV inputs as reported in terms of IFRS 7. A positive (negative) relationship between FVA (FVL) and PPS is expected and the coefficient estimate of FVA1 (FVL1) is predicted to be significantly different and larger than the FVA2 (FVL2) coefficient estimate, FVA1 (FVL1) to be significantly different and larger than FVA3 (FVL3) and lastly FVA2 (FVL2) to be significantly different and larger than FVA3 (FVL3).

The results show that FVA1, FVA2, FVA3 and FVL2 are significant and positively associated with PPS. The coefficients of FVL1 and FVL3 are positive but not statistically significant. Table 3 shows that all the FVA (FVL) levels are significantly priced differently from one another by investors with the exception of FVA1 and FVA3 where the differential pricing between the hierarchy levels is not significant.

Interestingly, the coefficients of FVA are following an ascending order meaning that FVA3 has a strong positive relationship with PPS compared to FVA2 and FVA1. These results contradict prior literature (Deaconu et al. 2010; Goh et al. 2009) in respect of the strength of pricing of FVA

TABLE 3: Pricing of fair value hierarchy levels - Dependent variable: Price per share at year-end.

\begin{tabular}{|c|c|c|c|c|c|}
\hline \multirow[t]{2}{*}{ Variable } & \multicolumn{2}{|c|}{ Unstandardised coefficients } & \multirow{2}{*}{$\begin{array}{c}\text { Standardised } \\
\text { coefficients: } \\
\text { Beta }\end{array}$} & \multirow[t]{2}{*}{$t$-statistic } & \multirow[t]{2}{*}{$p$} \\
\hline & B & Standard error & & & \\
\hline Intercept & 12058.977 & 6072.736 & - & 1.986 & $0.048 * *$ \\
\hline FVA1 & 0.698 & 0.348 & 0.398 & 2.005 & $0.046 * *$ \\
\hline FVA2 & 0.965 & 0.380 & 0.467 & 2.539 & $0.012 *$ \\
\hline FVA3 & 0.952 & 0.225 & 0.930 & 4.235 & $0.000 * * *$ \\
\hline FVL1 & 0.658 & 0.418 & 0.119 & 1.574 & 0.117 \\
\hline FVL2 & 0.584 & 0.312 & 0.297 & 1.872 & $0.062 *$ \\
\hline FVL3 & 0.919 & 1.785 & 0.022 & 0.515 & 0.607 \\
\hline $\mathrm{N}-\mathrm{FVA}$ & 0.895 & 0.318 & 1.483 & 2.818 & $0.005^{* * *}$ \\
\hline N-FVL & 0.937 & 0.343 & 1.646 & 2.736 & $0.007 * * *$ \\
\hline $\mathrm{NI}$ & 0.803 & 1.391 & 0.093 & 0.577 & 0.564 \\
\hline Adjusted $R^{2}$ & 0.671 & - & - & - & - \\
\hline Observations & 268.000 & - & - & - & - \\
\hline Comparison & - & - & - & - & - \\
\hline FVA1 - FVA2 & - & - & - & 2.036 & $0.043 * *$ \\
\hline FVA1 - FVA3 & - & - & - & 0.500 & 0.617 \\
\hline FVA2 - FVA3 & - & - & - & -0.215 & 0.830 \\
\hline FVL1 - FVL2 & - & - & - & 3.832 & $0.000 * * *$ \\
\hline FVL1 - FVL3 & - & - & - & -3.451 & $0.001 * * *$ \\
\hline FVL2 - FVL3 & - & - & - & -5.057 & $0.000 * * *$ \\
\hline
\end{tabular}

$*$, statistical significance level at $10 \%$ : least significant; **, statistical significance level at $5 \%$ : significant; $* * *$, statistical significance level at $1 \%$ : highly significant.

FVA, fair value assets; FVL, fair value liabilities; N-FVA, non-fair value assets; N-FVL, non-fair value liabilities; $\mathrm{NI}$, net income. 
hierarchy levels as $\mathrm{H} 1$ was not confirmed. Another anomaly per Table 3 is that FVL2 has a significant and positive relationship with PPS, contrary to our prediction.

Table 3 depicts the ordinary least square (OLS) for Equation 3. The first section details the coefficient estimates, standard errors, $t$-statistics and $p$-values. The second section details the adjusted R-squared and number of observations for the sample period 2013 to 2015 . The last section depicts the tests for significant differences on the OLS coefficient estimates between the different fair value assets (liabilities) levels.

As Equation 4 is a build-up from Equation 3, it simply adds the DE ratio to form Equation 4. This equation tests the impact of high DE ratio on the pricing of FVA2 and FVA3 as detailed in Table 4. A negative relationship is expected between companies with high DE and PPS in terms of $\mathrm{H} 2$.

In comparison to the coefficient estimates of Equation 3 (Table 3) FVA1, FVA2 and FVA3 coefficient estimates for Equation 4 have remained the same. The statistical significance of all the variables has also remained the same as in Table 3. The DE ratio coefficient estimate is an insignificant 0 . These results show that investors do not discount FVA2 (FVL2) and FVA3 (FVL3) of companies with high DE ratios in the financial sector, thus $\mathrm{H} 2$ was not confirmed.

Table 4 depicts the OLS for Equation 4 and the first section details the coefficient estimates, standard errors, $t$-statistics and $p$-values. The last section details the adjusted R-squared and number of observations for the sample period 2013 to 2015.

With $\mathrm{H} 3$ we are interested in the possible differential pricing by investors of FVA2 (FVL2) and FVA3 (FVL3) across the preand post-IFRS 13 periods. To test this hypothesis, we run Equation 3 for the two periods to determine the differences in the coefficient estimates across the two periods and the results are shown in Table 5 and Figure 1. The coefficient estimates for the pre-IFRS 13 period are generally higher than

TABLE 4: Pricing of fair value hierarchy levels: high debt equity companies Dependent variable: Price per share at year-end.

\begin{tabular}{lccccc}
\hline Variable & \multicolumn{2}{c}{ Unstandardised coefficients } & $\begin{array}{c}\text { Standardised } \\
\text { coefficients: } \\
\text { Beta }\end{array}$ & $\boldsymbol{t}$-statistic & $p$ \\
\hline Intercept & 12066.213 & 6114.729 & - & 1.973 & $0.050^{* *}$ \\
\hline FVA1 & 0.698 & 0.349 & 0.398 & 2.001 & $0.046 * *$ \\
FVA2 & 0.965 & 0.381 & 0.467 & 2.534 & $0.012^{* *}$ \\
FVA3 & 0.952 & 0.225 & 0.930 & 4.227 & $0.000^{* * *}$ \\
FVL1 & 0.658 & 0.419 & 0.119 & 1.571 & 0.117 \\
\hline FVL2 & 0.584 & 0.313 & 0.297 & 1.867 & $0.063^{*}$ \\
FVL3 & 0.918 & 1.794 & 0.022 & 0.512 & 0.609 \\
N-FVA & 0.895 & 0.318 & 1.483 & 2.812 & $0.005^{* * *}$ \\
N-FVL & 0.937 & 0.343 & 1.646 & 2.730 & $0.007 * * *$ \\
NI & 0.803 & 1.394 & 0.093 & 0.576 & 0.565 \\
DE & -0.681 & 57.126 & 0.000 & -0.012 & 0.990 \\
\hline
\end{tabular}

*, statistical significance level at $10 \%$ : least significant; **, statistical significance level at $5 \%$ : statistically significant; $* * *$, statistical significance level at $1 \%$ : statistically highly significant. FVA, fair value assets; FVL, fair value liabilities; N-FVA, non-fair value assets; N-FVL, non-fair value liabilities; NI, net income; $\mathrm{DE}$, debt equity. the post-IFRS 13 period. Across the two periods the coefficients estimates follow a similar trend except the coefficient estimates of FVA3 which follow a downward trend for the pre-IFRS 13 period and the post-IFRS 13 period shows an upward trend. The adjusted $\mathrm{R}^{2}$ has increased in the post-IFRS 13 period, thus the explanatory power of the variables increased in the post-IFRS 13 period, compared to the pre-IFRS 13 period, implying that the introduction of IFRS 13 had a positive effect on the pricing of FVA3.

Table 5 depicts the OLS for Equation 3 and the second column details the coefficient estimates of the pre-IFRS 13 period and the third column details the post-IFRS 13 period. The last column details the difference of the coefficient estimates between the two periods and the last section details the adjusted R-squared.

With $\mathrm{H} 4$ we are interested in the possible differential pricing by investors of FVA (FVL) during and in the period after the 2008 financial crisis period. To test this hypothesis, we run Equation 3 for the two periods to determine the differences in the coefficient estimates across the two periods and the results are shown in Table 6 and Figure 2. The coefficient estimates for the period during the financial crisis are generally higher than in the period afterwards. Across the two periods the coefficients estimates follow a similar trend

TABLE 5: Pricing of fair value hierarchy levels: Pre- and post-IFRS 13.

\begin{tabular}{lccc}
\hline Variable & Pre-IFRS 13 & Post-IFRS 13 & Post-IFRS 13 - pre-IFRS 13 \\
\hline FVA1 & 1.227 & 0.398 & -0.829 \\
FVA2 & 1.492 & 0.467 & -1.025 \\
FVA3 & 0.287 & 0.930 & 0.643 \\
FVL1 & 0.356 & 0.119 & -0.237 \\
FVL2 & 1.092 & 0.297 & -0.795 \\
FVL3 & 0.151 & 0.022 & -0.129 \\
N-FVA & 4.608 & 1.483 & -3.125 \\
N-FVL & 5.010 & 1.646 & -3.365 \\
NI & 0.247 & 0.093 & -0.155 \\
Adjusted $R^{2}$ & 0.658 & 0.680 & - \\
\hline
\end{tabular}

FVA, fair value assets; FVL, fair value liabilities; N-FVA, non-fair value assets; N-FVL, non-fair value liabilities; $\mathrm{NI}$, net income.



FVA, fair value assets; FVL, fair value liabilities; N-FVA, non-fair value assets; N-FVL, non-fair value liabilities; $\mathrm{NI}$, net income.

FIGURE 1: Depiction of pricing of fair value hierarchy levels pre- and post-IFRS 13. 
TABLE 6: Pricing of fair value hierarchy levels: During and after the 2008 financial crisis.

\begin{tabular}{lccc}
\hline Variable & During crisis & Post crisis & Post crisis - during crisis \\
\hline FVA1 & 1.533 & 0.438 & -1.094 \\
FVA2 & 1.808 & 0.515 & -1.293 \\
FVA3 & 0.339 & 0.859 & 0.520 \\
FVL1 & 0.415 & 0.132 & -0.283 \\
FVL2 & 1.481 & 0.322 & -1.159 \\
FVL3 & 0.451 & 0.011 & -0.439 \\
N-FVA & 5.928 & 1.635 & -4.293 \\
N-FVL & 6.309 & 1.819 & -4.490 \\
NI & 0.149 & 0.138 & -0.011 \\
Adjusted $R^{2}$ & 0.715 & 0.674 & - \\
\hline
\end{tabular}

FVA, fair value assets; FVL, fair value liabilities; N-FVA, non-fair value assets; N-FVL, non-fair value liabilities; $\mathrm{NI}$, net income.



FVA, fair value assets; FVL, fair value liabilities; N-FVA, non-fair value assets; N-FVL, non-fair value liabilities; $\mathrm{NI}$, net income.

FIGURE 2: Depiction of pricing of fair value hierarchy levels during and after the 2008 financial crisis.

except the coefficient estimates of FVA3 which follows a downward trend for the period during the crisis and in the period after the crisis shows an upward trend. This evidence shows that during the financial crisis period investors discounted FVA3 compared to the period after the financial crisis period, which is consistent with the assertion made by Goh et al. (2009). The adjusted $R^{2}$ has decreased in the period after the crisis period. The explanatory power of the variables decreased in the period after the crises.

Table 6 depicts the OLS for Equation 3 and the second column details the coefficient estimates of the period during the financial crisis and the third column details the post period. The last column details the difference of the coefficient estimates between the two periods and the last section details the adjusted R-squared.

\section{Robustness tests: Different industries}

To address the possible confounding effects on the testing of $\mathrm{H} 1$ and $\mathrm{H} 2$ due the heterogeneity of the sample, we stratified the sample into different industries within the financial sector. For FVA we expect the coefficient estimates to be positive and for FVL, it to be negative; this arises from the theoretical construct of the accounting equation which assumes that equity is equal to assets, less liabilities. Therefore, a positive (negative) FVA (FVL) and statistically significant coefficient estimate means the concerned FVA (FVL) hierarchy level has a positive (negative) effect on PPS. The untabulated results for $\mathrm{H} 1$ in respect of the different industries show that the FVA1 and FVA2 coefficient estimates for the insurance and investment instruments industries are positive and significant, thus positively associated with PPS. In the other industries, the coefficient estimates are not significant for FVA1 and FVA2. In respect of FVA3, only the insurance, investment instruments and real estate have positive and significant coefficient estimates, thus positive association with PPS.

The FVL1, FVL2 and FVL3 coefficient estimates in the insurance industry are positive and significant, therefore positively associated with PPS. The signs of the coefficient estimates for these variables contradict our prediction. For the investment instruments industry, FVL1 is significant and negatively associated with PPS and for the financial services industry FVL3 is significant and negatively associated with PPS. Furthermore, the untabulated results show that the insurance industry has coefficient estimates that follow a descending order and are significant in respect of FVA, confirming H1. All the FVL hierarchy levels coefficient estimates are significant for this industry; however, they are not following a descending order. $\mathrm{H} 1$ is therefore not confirmed in respect of FVL. For the investment instruments industry, the FVA coefficient estimates are significant, but they are not in a descending order, thus $\mathrm{H} 1$ is not confirmed. For the other industries within the financial sector, $\mathrm{H} 1$ is not confirmed due to lack of significant coefficient estimates within all the FVA and FVL hierarchy levels.

For H2, we are mainly interested in the coefficient estimates for the DE ratio and we expect a negative coefficient estimate, implying that investors discount PPS of companies with high DE ratios. The untabulated results show that the financial services industry with high DE has a significant and positive association with PPS, contrary to our expectation. Further, the results show that the introduction of a high DE ratio variable in the financial services industry leads to significant FVA1, FVL2 and FVL3 coefficient estimates. Consequently, FVA1 and FVL2 (FVL3) become positively (negatively) associated with PPS, implying that investors are affected by companies with high DE ratios in respect of pricing FVA2 (FVL2) and FVA3 (FVL3). Therefore, the results show support for $\mathrm{H} 2$ in respect of the insurance industry. It is also worthy to note that the regression results for Equation 4 in respect of the banking, investment instruments and real estate industries are similar to the results of Equation 3 in respect of FVA and FVL. Thus, a high DE ratio has no impact on the pricing of PPS and FVA and FVL in these industries.

\section{Conclusion}

This article investigates the pricing of fair value assets and liabilities hierarchy levels as disclosed in terms of IFRS 7. The article further investigates the effects of high debt 
equity ratio and possible differential pricing effects as a result of the introduction of IFRS 13 and the impact of the 2008 financial crisis. The H1 results reveal that fair value assets across the three hierarchy levels are positively associated with share price. Contrary to the theoretical construct of the accounting equation, our results concluded that fair value liabilities hierarchy level 2 are positively associated with share price which presents a literature gap for future studies. All the fair value assets and liabilities hierarchy levels are priced differently, except the pricing for fair value assets level 1 and 3. H1 was not confirmed in respect of the financial sector as a whole, but was confirmed for the insurance industry in respect of fair value assets. Our $\mathrm{H} 2$ results found that investors in the financial sector do not discount fair value assets and liabilities in respect of companies with a high debt equity ratio, but they place a discount on fair value assets and liabilities level 2 and 3 in the insurance industry.

The H3 results reveal that the introduction of IFRS 13 had a positive pricing effect on fair value assets level 3 in respect of share price. To test $\mathrm{H} 3$ we examined the differences within the variables between the pre- and post-IFRS 13 period and considered trend analysis. The adjusted $\mathrm{R}^{2}$ for post-IFRS 13 increased, confirming that results have more explanatory power in comparison to the pre-IFRS 13 period. A limitation of this study is that the differences within the variables were not examined statistically but this can be addressed in future research.

The H4 results reveal that in comparison to the period before and during the 2008 financial crisis, the pricing of fair value assets level 3 improved in the period after the 2008 financial crisis. However, the explanatory power of the variables used to test $\mathrm{H} 4$ decreased in the post-crisis period in comparison to the pre-2008 financial crisis period, as evidenced by the decline in the adjusted $\mathrm{R}^{2}$. These tests also involved a consideration of the differences within the variables between the periods during and after the 2008 financial crisis and trend analysis. The limitation stated for the $\mathrm{H} 3$ result is also applicable.

\section{Acknowledgements}

All the reviewers for their comments and suggestions on the article.

\section{Competing interests}

The authors declare that they have no financial or personal relationships that may have inappropriately influenced them in writing this article.

\section{Authors' contribution}

H.H. was the main author of the study. M.Z. was co-author and responsible for improving the quality of the study, as well as incorporating the reviewers' comments.

\section{References}

Barth, M.E., 2007, 'Standard-setting measurement issues and the relevance of research', Accounting and Business Research 37(sup1), 7-15. https://doi.org/10 $.1080 / 00014788.2007 .9730079$

Barth, M.E., Beaver, W.H. \& Landsman, W.R., 1996. 'Value-relevance of banks' fair value disclosures under SFAS No. 107', Accounting Review 71(4), 513-537.

Barth, M.E., Beaver, W.H. \& Landsman, W.R., 2001, 'The relevance of the value relevance literature for financial accounting standard setting: Another view', Journal of Accounting and Economics 31(1-3), 77-104. https://doi.org/10.1016/ S0165-4101(01)00019-2

Barth, M.E. \& Clinch, G., 2009, 'Scale effects in capital markets-based accounting research', Journal of Business Finance and Accounting 36(3-4), 253-288. https:// doi.org/10.1111/j.1468-5957.2009.02133.x

Barth, M.E. \& Landsman, W.R., 1995, 'Fundamental issues related to using fair value accounting for financial reporting', Accounting Horizons 9(4), 97-107.

Business Cycle Dating Committee, 2010, National bureau of economic research, NBER Cambridge.

Carroll, T.J., Linsmeier, T.J. \& Petroni, K.R., 2003, 'The reliability of fair value versus historical cost information: Evidence from closed-end mutual funds', Journal of Accounting, Auditing \& Finance 18(1), 1-24.

Deaconu, A., Buiga, A. \& Nistor, C.S., 2010, 'The value relevance of fair value', Transition Studies Review 17(1), 151-169. https://doi.org/10.1007/s11300-010-0131-9

Dechow, P.M., Myers, L.A. \& Shakespeare, C., 2010, 'Fair value accounting and gains from asset securitizations: A convenient earnings management tool with compensation side-benefits', Journal of Accounting and Economics 49(1-2), 2-25. https://doi.org/10.1016/j.jacceco.2009.09.00

De Klerk, M., De Villiers, C. \& Van Staden, S., 2015, 'The influence of corporate social responsibility disclosure on share prices : Evidence from the United Kingdom', Pacific Accounting Review 27(2), 208-228. https://doi.org/10.1108/PAR-05-2013-0047

Easley, D., Hvidkjaer, S. \& O'Hara, M., 2002, 'Is information risk a determinant of asset returns?', Journal of Finance 57(5), 2185-2221. https://doi.org/10.1111/15406261.00493

Epstein, L.G. \& Schneider, M., 2008, 'Ambiguity, information quality, and asset pricing author(s)', The Journal of Finance 63(1), 197-228. https://doi.org/10.1111/j.15406261.2008.01314.x

Goh, B.W., Ng, J. \& Ow Yong, K., 2009, 'Market pricing of banks' fair value assets reported under SFAS 157 During the 2008 financial crisis', Capana Conference, July 2-3 2009, Beijing, China, pp. 1-41. Available at http://www.capana.net/ download/2009papers/Beng\%20Wee\%20Goh.pdf

Healy, P.M. \& Palepu, K.G., 2001, 'Information asymmetry, corporate disclosure, and the capital markets: A review of the empirical disclosure literature', Journal of Accounting and Economics 31(1-3), 405-440. https://doi.org/10.1016/S01654101(01)00018-0

Holmström, B.R. \& Tirole, J., 2001, 'LAPM: A liquidity-based asset pricing model', MIT Dept. of Economics Working Paper No. 98-08. https://doi.org/10.2139/ssrn.237497 IASB, 2005a, IFRS 7 financial instruments: Disclosure, IASB, London.

IASB, 2005b, Press release. IASB issues standards to improve disclosures about financial instruments and capital, IASB, London.

IASB, 2008, Reclassification of financial assets - Amendments to IAS 39 financial instruments: Recognition and measurement and IFRS 7 financial instruments: Disclosures, amendment, IASB, London.

IASB, 2010, Conceptual framework for financial reporting, IASB, London.

IASB, 2011, IFRS 13 fair value measurement, IASB, Lodnon.

Kadous, K., Koonce, L. \& Thayer, J.M., 2012, 'Do financial statement users judge relevance based on properties of reliability?', Accounting Review 87(4), 13351356. https://doi.org/10.2308/accr-50157

Landsman, W., 1986, 'An empirical investigation of pension fund property rights', Accounting Review 61(4), 662-691.

Laux, C. \& Leuz, C., 2009, 'The crisis of fair-value accounting: Making sense of the recent debate', Accounting, Organizations and Society 34(6-7), 826-834. https:// doi.org/10.1016/j.aos.2009.04.003

Ohlson, J.A., 1995, 'Earnings, book values, and dividends in equity valuation', Contemporary Accounting Research 11(2), 661. https://doi.org/10.1111/j.1911-3846.1995. tb00461.x

Penman, S.H., 2007, 'Financial reporting quality: Is fair value a plus or a minus?', Accounting and Business Research 37(Suppl. 1), 33-44. https://doi.org/10.1080 /00014788.2007.9730083

Petroni, K.R. \& Wahlen, J.M., 1995, 'Fair values of equity and debt securities and share prices of property-liability insurers', The Journal of Risk and Insurance 62(4), 719737. https://doi.org/10.2307/253592

Procházka, D., 2011, 'The role of fair value measurement in the recent financial crunch', Economics, Management and Financial Markets 6(1), 989.

Song, C.J., Thomas, W.B. \& Yi, H., 2010, 'Value relevance of FAS No. 157 fair value hierarchy information and the impact of corporate governance mechanisms', Accounting Review 85(4), 1375-1410. https://doi.org/10.2308/accr.2010.85.4.1375

World Economic Forum, 2016, Global competitiveness index 2016-2017, viewed 27 August 2018, from http://reports.weforum.org/africa-competitivenessreport-2017/files/2017/05/SouthAfrica.pdf 